A vote of thanks to the Director closed the proceedings, and the party returned to town by the 8.33 train from Reigate.

\title{
REFERENCES.
}

Geological Survey Map, r-inch, Sheet 8, 8s, 6d.

Geological Survey Index Map, Sheet I2, 2s. 6d.

One-inch Ordnance Survey Map (New Edition), Sheet 286, Is.

1875. TopLEY, W.-"The Geology of the Weald." Mem. Geol. Survey.

1887. TOPLEY, W.- "Excursion to Merstham, Redhill, and Reigate." Proc. Geol. Assoc., vol. x, p." 154.

I887. WOODWARD, H. B.-"The Geology of England and Wales." Second Edition, pp. 367-372.

I895. LeIghtoN, T.- "The Lower Greensand above the Atherfield Clay of E. Surrey." Quart. Fourn. Geol. Soc, vol. li, p. IOr.

I902. Stebring, W. P. D., and Whitaker, W.- "Excursion to Reigate and Redhill." Proc. Geol. Assoc., vol, xvii, P. 385.

\section{EXCURSION TO BISHOP'S STORTFORD AND STANSTED.}

$$
\text { JULY I5TH, } 1905 \text {. }
$$

Director: The Rev. A. Irving, D.Sc., B.A., And Mr, Percy A. Irving.

\section{Excursion Secretary: T. W. READER, F.G.S.}

THE party left Liverpool Street (G.E.R.) by the r.23 p.m. train and arrived at Stansted at 2.40 p.m. They were met by the Directors and proceeded to the old Chalk pit at the Castle Hill, where a fault was seen which had equally affected the Chalk, the Reading Beds, and the overlying gravels. The downthrow of about $6 \mathrm{ft}$. was to the north. The large gravel pits close to the station were next visited. Here, at $225 \mathrm{ft}$. O.D., from 30 to $40 \mathrm{ft}$. of gravels and boulder drift of the valley were exposed. The section in the station pit taken transversely to the line of the valley gives at the present time the following succession :-

(c) Boulder Clay, including subordinated zones of feebly-stratified silty matter.

(b) Glacial boulder detritus; almost made up of flint boulders and some angular blocks, with oceasional boulders of palæozoic and mesozoic rock material .

(a) Stratified gravel with a slight 'horse-back' arrangement, containing much small rolled chalk detritus, along with triassic and other débris from the older rocks . . . . . . .

Dr. Irving stated that in this section, two remarks were admissible : 
(r) A large proportion of the flint boulders (b) must, from their weathered appearance, have undergone long exposure at the surface before their accumulation here, even as the flints picked off the land and built along with palæozoic boulders into numerous walls of churches, etc., all over this side of England show signs of exposure.

(2) The abundance of small chalk pebbles in the lowest deposit $(a)$, may be taken to indicate the stage of the fluviatile erosion of the ancient Mercian region in Tertiary times at which the attenuated cretaceous strata, extending then far beyond the present Chalk escarpment, were being sawn through.*

Leaving these interesting and instructive sections, the party proceeded to a Chalk pit near Brooklands, where a junction between the Chalk and Tertiaries was seen. At Foxdells a section was seen showing "Rubble" overlain by coarse material containing blocks of older rocks than the Chalk, and by a wellstratified gravel containing much finer Chalk detritus. Rolled fragments of granite, of several basic crystalline rocks, Carboniferous limestone and various quartzites were obtained here. The proprietor of the pit, Mr. John Barker, J.P., then welcomed the party to his residence, The Grange, and provided welcome hospitality.

As the party proceeded in the drag along the Cambridge Road towards Stortford, the Director pointed out that the high ground of Birchanger to the east was capped by London Clay, of which bricks were made. The sections are now obscure, but they formerly yielded sharks' teeth, septaria, etc. The base of the formation was marked by a band of black flint pebbles and oysters, where the sands of the Reading series below were dug out.

At Mr. J. Day's brickworks, Rye Street, Bishop's Stortford, the clunchy character of the bed reposing immediately upon the Chalk, with green-coated flints (as at Reading), was pointed out by the Director. A number of specimens of Micraster cor-anguinum have during the past few years been obtained from this pit.

A drive through the town to the gravel pits on the Hallingbury Road, that belonging to Sir Walter Gilbey, on the Hockerill Park Estate, and the much more extensive one belonging to the Urban District Council were visited. From the former of these the "shingle" newly laid down at Hockerill Vicarage was obtained, full of triassic rolled débris. The larger pit was more closely inspected, where the well-stratified gravels were seen passing up into stratified gravelly sands, the whole capped with Boulder Clay. These constitute the terrain of the high ground of Hockerill Park Estate, the Director mentioning that recent excavations for building and deep sewers (in one case $18 \mathrm{ft}$. deep) had proved the powerful development of the very chalky Boulder Clay in that

- Cf. A Ramsay, "Physical Geology and Geography or Great Britain," Fig. 29, (p. $31_{3}$, Ed. 5) ; also the recent work of Dr. A. E. Salter, F.G.S., in Proc. Geol. Assoc., vol. xix, pp. i et seg. 
locality, with large angular blocks of palæozoic and mesozoic rocks, as well as flints from the Chalk. The two pits on the Thorley side of the valley represent the gravels in their most ancient character, extremely indurated with layers conglomerated by carbonate of iron, in both cases overlain also by the Boulder Clay of the district, here with very little chalky stuff in it, though a little farther to the north, near the cemetery, it again takes on the chalky character. A pretty full account of the larger and older pit, that belonging to Mr. Laurie Frere, was given in 1897 ; but the new pit opened by the London Road since that time is of exceptional interest. A certain transverse quaquaversal arrangement of the stratification of the gravels was observed in the older and larger pit as it was worked; but in the smaller and newer pit a little to the north that arrangement is very striking; as is also the marked unconformity, the shingle-bank having had its ridge planed off before the Boulder Clay was dropped upon it.

In the 1897 paper there is given a list of ten well-sections at Bishop's Stortford, in which the Chalk was reached at depths below the present alluvial plain of the valley varying from $5 \circ$ to $170 \mathrm{ft}$., the details of the deepest being given according to the account furnished by the well-sinker, Mr. Ingold. More definite information is now in the writer's possession from a section at another well at the Anchor Maltings, recently sunk by his successor, Mr. Featherby, who accompanied the party on July ${ }_{1}{ }_{5}$ th. The specimens were arranged for inspection with a sectional drawing to scale of the well, by Mr Percy Irving. The succession is as follows :-

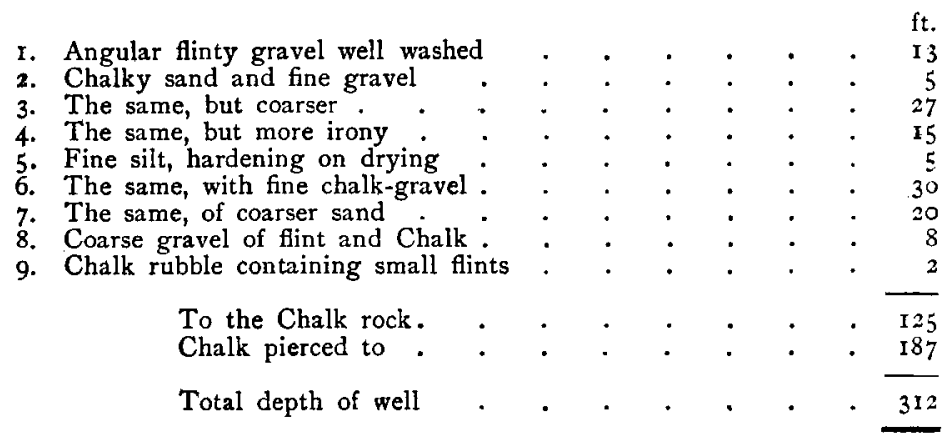

All the specimens 2 to 9 are highly calcareous. The question left open in 1897 as to the possible identity of these well-sectioned deposits in the Stort alluvium with the Stansted gravels is now answered decidedly in the negative; and the diagnosis of the buried valley and its contents would appear to be pretty complete. Further details, as they come to hand, may necessitate slight modifications in its reading here and there, but are not likely to 
invalidate the history of the valley which data at present to hand have enabled us to construct, as that of an ancient Tertiary valley of a great affuent of the Lower Thames-Rhine estuary, its inception, dating back at least to Miocene times, more or less obliterated since, during the Glacial Period, and by recent alluvial deposits, while at Stansted and a little farther down the amount of post-glacial work of erosion done by the present stream can be observed.

The day wound up with tea at Hockerill Vicarage, together with a study of well-sections along with a great variety of rockmaterial collected from the Boulder Clay of the Herts and Essex border by $\mathrm{Mr}$. Percy Irving, and a collection of specimens obtained by the same from the base of the Bunter Sandstone near Mansfield, Notts, for comparison with the triassic débris found in the gravels and the Boulder Clay.

\section{REFERENCES.}

Ordnance Survey Map (New Series), 222, Is.

Geological Survey Map, Sheet 47, Drift (Old Series), price 8s. 6d.

1890. PREsTWICH, J.- "The Westleton Beds and their Relations" (three papers). Quart. Fourn. Geol. Soc., vol. xlvi, pp. 84, I20, I55.

I89o. IRving, A.- "Plateau Gravels of Berks and Surrey," Quart. Fourn. Geol. Soc., vol. xlvi, p. 557.

I890. IRving, A.- "Note on the Elevation of the Weald." Grol.Mag., vol. vii, p. 403 .

1892. MonckTon, H. W.-. "Gravels South of the Thames," Quart. Fou'n. Geol. Soc., vol. xlviii, p. 29.

I893. IRving, A.- "Surface Changes in the London Basin." Geol. Mag." vol. $x$, p. 2 II.

1896. SAlter, A. E.-" Pebbly Gravel from Goring Gap to the Norfolk Coast." Proc. Geol. Assoc., vol. xiv, p. 389.

I897. Osborne White, H. J.- "Origin of the High Level Gravel with Triassic Débris." Proc. Geol. Assoc., vol. xv, p. I57.

I898. IRving, A.- "Geology of the Stort Valley." Proc. Geol. Assoc., vol. $\mathrm{xv}, \mathrm{p} .193$.

IRving, A.-"The High-Level Plateau Gravels on the North Side of the Tamisian Area, etc."-Geol. Mag., Dec. V, vol. i, Oct., I904.

1905. Salter, A. E.- "The Superficial Deposits of Central and Southern England."-Proc. Geol. Assoc., vol xix, pp. I-56.

1905. Salter, A. E.- "The Gravels of Hertfordsbire." Trans, Herts. Nat. Hist. Soc., vol. xii, Pp. I4I and 143. 